\title{
Relationship Between Calcium Intake, Serum Ionized Calcium and Elevated Blood Pressure in Primigravida after 24 weeks of Gestation
}

\author{
Lukman Halim*, Savitri Sayogo**, Handaja***
}

\begin{abstract}
Abstrak
Data Survei Kesehatan Rumah Tangga tahun 1992 memperlihatkan angka kematian ibu di Indonesia masih tinggi, 425 per 100.000 kelahiran hidup. Salah satu penyebab kematian ibu ialah Eklampsia. Penyebab eklampsia belum diketahui dengan pasti, namun selalu didahului dengan Preeklampsia. Hasil penelitian para ahli membuktikan terdapat hubungan terbalik antara masukan Kalsium (Ca) dengan angka kejadian Preeklampsia. Penelitian ini bertujuan untuk membuktikan adanya hubungan antara masukan Ca, kadar ion Ca serum dengan kejadian Preeklampsia. Subyek penelitian meliputi 86 primigravida dengan usia kehamilan 24 minggu kemudian diikuti sampai usia kehamilan 36 minggu. Hasil penelitian menunjukkan bahwa masukan Ca pada usia kehamilan 24, 32 dan 36 minggu masing-masing 63\%, 67\% dan 63\% dari Angka Kecukupan Gizi (AKG). Kadar ion Ca serum pada usia kehamilan 24 dan 36 minggu, masing-masing 1,06 dan 1,05 mmol/. Angka kejadian Preeklampsia didapatkan sebanyak 8,1\%, 1 orang didiagnosis pada usia kehamilan 32 minggu, sisanya pada usia kehamilan 36 minggu. Analisis statistik tidak mendapatkan hubungan yang bermakna antara masukan Ca, kadar ion Ca serum dengan Preeklampsia $(p>0,05)$.
\end{abstract}

\begin{abstract}
Data from the 1992 National Household Survey revealed that Maternal Mortality Rate (MMR) in Indonesia was still high, 425 per 100,000 live births. One of the major cause of this high MMR is Eclampsia. Research has shown an inversed relationship between calcium ( $\mathrm{Ca}$ ) intake and the incidence of Preeclampsia. Preeclampsia it self can be followed by Eclampsia. This study involving 86 primigravidas observed from 24 weeks to 36 weeks of gestation. The result showed Ca intake on 24th, 32nd and 36th weeks of gestation were $63 \%, 67 \%$ and $63 \%$ of the Recommended Dietary Allowances (RDA) respectively. Serum ionized Ca on 24th and 36th weeks of gestation were 1.06 and $1.05 \mathrm{mmol} / \mathrm{l}$. The incidence of Preeclampsia was $8,1 \%, 1$ diagnosed at 32 weeks of gestation and the other at 36 weeks of gestation. Statistical analysis showed no significant relationship between Ca intake, serum ionized Ca and the incidence of Preeklampsia $(p>0.05)$.
\end{abstract}

Keywords: calcium, preeclampsia, primipravida

\section{INTRODUCTION}

It was noted that Indonesia had the highest Maternal Mortality Rate (MMR) among the Asean Countries. Data from The 1992 National Household Survey showed that MMR decreased from 450 per 100,000 live births to 425 per 100,000 live births in 1992. One of the major cause of this high MMR is Eclampsia. It was revealed that Preeclampsia, a Pregnancy-induced hypertension with proteinuria and or edema could be a serious complication to Eclampsia. ${ }^{1}$ From several studies in Indonesia, the incidence of Preeclampsia

\footnotetext{
* Department of Nutrition, Faculty of Medicine, Trisakti University, Jakarta, Indonesia

** Department of Nutrition, Faculty of Medicine. University of Indonesia, Jakarta, Indonesia

*** Department of Obstetrics and Gynaecology, Faculty of Medicine, University of Indonesia, Jakarta, Indonesia
}

was known to be between 4 to $17.5 \%{ }^{2,3,4,5}$ Pregnancy represent a very special and demanding period for calcium (Ca) needs and requirements. Furthermore, pregnancy is a period of high $\mathrm{Ca}$ demands due to fetal requirements. At the end of pregnancy, fetal $\mathrm{Ca}$ accumulation totals approximately 30 grams. The transport of ionized $\mathrm{Ca}$ from the mother to the fetus increases from about 50 grams per 24 hours at 20 weeks of gestation to a maximum of about 330 grams per 24 hours at 35 weeks of gestation. ${ }^{6}$ Epidemiologic investigations, laboratory evaluations and clinical trials all confirmed that the relationship between $\mathrm{Ca}$ and blood pressure extends to include the pregnant state. On the basis of current information it was clear the $\mathrm{Ca}$ supplementation during pregnancy lowers blood pressure. Additionally the effect of $\mathrm{Ca}$ on blood pressure may influence the incidence of preeclampsia. ${ }^{7} \mathrm{Al}-$ though the mechanism for these effects has not been entirely elucidated, $\mathrm{Ca}$ supplementation appears to af- 
fect circulating concentration of parathyroid hormone and renin, which may modulated intracellular ionized $\mathrm{Ca}$, resulting in its observed effect on smooth-muscle relaxation. ${ }^{8}$ The purpose of this study was to determine the relationship between $\mathrm{Ca}$ intake, serum ionized $\mathrm{Ca}$ and the incidence of Preeclampsia in primigravida after 24 weeks of gestation.

\section{METHODS}

The design of this study is a cross sectional, followed by follow-up study from 24 weeks to 36 weeks of gestation involving 110 pregnant women. Fourty eight women were out patients of Department of Obstetrics and Gynaecology Faculty of Medicine, University of Indonesia/ National General Hospital Cipto Mangunkusumo (RSUPNCM) and 62 came from Maternity Hospital Budi Kemuliaan (RSBBK) in Jakarta. The study was conducted from March 1996 until August 1996.

The inclusion criteria for subjects of this study were primigravida without any serious illness, none of subjects had a history of hypertension, cardiac and gastrointestinal tract diseases, blood pressure within a normal limits, no edema, normal blood urea and creatinine and negative urine protein. At enrollment, subjects were interviewed to identify their age, level of education and level of income. Body weight, blood pressure, dietary evaluation using 2 days recall method for calorie, protein and $\mathrm{Ca}$ intakes and blood examination for serum ionized $\mathrm{Ca}$ were also measured.

Follow up study consisted of three observations, on 28 th, 32 nd and 36 th weeks of gestation. On 28th weeks of gestation examination was for blood pressure, on 32 nd weeks of gestation were 2 days recall method, blood pressure and on 36th weeks of gestation were 2 days recall method, blood pressure and serum ionized Ca. Nutritional status was determined using "Kartu Menuju Sehat Ibu Hamil". Statistic analysis done using chi square and Anova.

\section{RESULT}

Eleven of the 48 subjects from RSUPNCM and 13 of the 62 subjects from RSBBK were excluded from this study because they did not complete the program. The characteristic of 86 subjects who followed the study were: $89 \%$ below the age of 30 years, $77 \%$ were middle level of education, $55 \%$ working, $77 \%$ medium income level and $62 \%$ in good nutritonal status. (Table 1).
Table 1. Characteristic of subjects

\begin{tabular}{lcc}
\hline Characteristic & Sum $(\mathrm{n}=86)$ & $\%$ \\
\hline Age & & \\
$\quad<24$ years & 39 & 45 \\
$25-29$ years & 38 & 44 \\
$\quad 30->$ & 9 & 11 \\
Education & & \\
$\quad$ Low & 5 & 6 \\
$\quad$ Middle & 66 & 77 \\
$\quad$ High & 15 & 17 \\
Activity & & \\
$\quad$ Work & 47 & 55 \\
$\quad$ Not work & 39 & 45 \\
Income & & \\
$\quad$ Low & 20 & 23 \\
$\quad$ Middle & 66 & 77 \\
Nutritional status & & 38 \\
$\quad$ Under & 33 & 62 \\
$\quad$ Good & 53 & \\
\hline
\end{tabular}

The mean calorie intake at 24,32 , and 36 weeks of gestation were $1592 \pm 358,1630 \pm 352,1628 \pm 298$ $\mathrm{Kcal} /$ days, mean protein intake were $59 \pm 16,63 \pm 16$, $63 \pm 16 \mathrm{grams} /$ day and mean Ca intake were $568 \pm$ $233,604 \pm 204,563 \pm 203 \mathrm{mg} /$ day respectively. The result of calorie, protein and $\mathrm{Ca}$ intakes according to the Recommended Dietary Allowances (RDA) are shown in Table 2. Most were below RDA, except protein intake at 32 and 36 weeks of gestation. Mean serum ionized $\mathrm{Ca}$ on 24th and 36th weeks of gestation were $1.06 \pm 0.06$ and $1.05 \pm 0.05 \mathrm{mmol} / \mathrm{l}$ respectively.

Table 2. Result of Calorie, Protein and $\mathrm{Ca}$ intakes according to Recommended Dietary Allowances ( \% Mean \pm Standard Deviation).

\begin{tabular}{lrrr}
\hline & 24th weeks & 32nd weeks & 36th week \\
\hline Calorie & $68.2 \pm 15.3$ & $69.8 \pm 15.1$ & $69.7 \pm 12.8$ \\
Protein & $98.3 \pm 26.7$ & $105.0 \pm 26.7$ & $105.0 \pm 26.7$ \\
Calcium & $63.1 \pm 25.9$ & $67.1 \pm 22.7$ & $62.6 \pm 22.6$ \\
\hline
\end{tabular}

Table 3. Association between calcium intake and serum ionized calcium concentration on 24 th and 36 th weeks of gestation.

\begin{tabular}{ccccc}
\hline \multicolumn{5}{c}{ Ionized Ca (mmol/L) } \\
$<1,03$ & $\geq 1,03$ & OR & CI \\
\hline 24th weeks of gestation & & & & \\
Ca intake(mg/day) & & & & \\
$<90 *^{*}$ & 21 & 57 & & - \\
$\geq 900$ & 0 & 8 & & \\
36th weeks of gestation & & & & \\
Ca intake(mg/day) & & & & \\
$<900$ & 25 & 55 & 1,89 & $0,18-46,72$ \\
$\geq 900$ & 1 & 4 & & \\
\hline
\end{tabular}

* $0.05 \quad \mathrm{OR}=$ Odds ratio; $\mathrm{CI}=$ Confidence interval 
There was no significant difference between Ca intake and serum ionized $\mathrm{Ca}$ at 24 and 36 weeks of gestation (Table 3).

Table 4. Mean and standard deviation of blood pressure on weeks of gestation

\begin{tabular}{|c|c|c|c|c|c|}
\hline \multirow[b]{2}{*}{$\begin{array}{l}\text { Blood } \\
\text { pressure }\end{array}$} & \multicolumn{5}{|c|}{ Weeks of gestation } \\
\hline & 24 wks & 28 wks & 32 wks & $36 \mathrm{wks}$ & $\mathrm{p}$ \\
\hline Systolic(mHg) & $105 \pm 9$ & $106 \pm 10$ & $107 \pm 10$ & $109 \pm 10$ & $<0.05$ \\
\hline Diastolic(mmHg) & $69 \pm 7$ & $70 \pm 7$ & $71 \pm 7$ & $72 \pm 8$ & $<0.05$ \\
\hline
\end{tabular}

There was an increased systolic and diastolic blood pressure at 24 and 36 weeks of gestation, but no significant difference (Table 4).

Table 5. Association between systolic blood pressure and variable factors on 24 th and 36 weeks of gestation.

\begin{tabular}{|c|c|c|c|c|}
\hline \multirow[b]{2}{*}{ Variables } & \multirow[b]{2}{*}{$\mathrm{n}$} & \multicolumn{3}{|c|}{$\begin{array}{l}\text { Systolic Blood Pressure } \\
(\mathrm{mmHg})\end{array}$} \\
\hline & & 24 weeks & n & 36 weeks \\
\hline \multicolumn{5}{|l|}{ Age(year) } \\
\hline$<-24$ & 39 & $104 \pm 9$ & 39 & $109 \pm 11$ \\
\hline $25-29$ & 38 & $105 \pm 10$ & 37 & $109 \pm 10$ \\
\hline $30-$ & 9 & $109 \pm 6$ & 9 & $109 \pm 8$ \\
\hline \multicolumn{5}{|l|}{ Education } \\
\hline Low & 5 & $104 \pm 6$ & 5 & $110 \pm 7$ \\
\hline Middle & 66 & $104 \pm 9$ & 66 & $109 \pm 11$ \\
\hline High & 15 & $109 \pm 11$ & 14 & $110 \pm 5$ \\
\hline \multicolumn{5}{|l|}{ Income } \\
\hline Low & 20 & $108 \pm 11$ & 19 & $110 \pm 11$ \\
\hline Middle & 66 & $104 \pm 9$ & 66 & $109 \pm 1$ \\
\hline \multicolumn{5}{|l|}{ Nutritional status } \\
\hline Under & 33 & $101 \pm 7 *$ & 33 & $106 \pm 9 *$ \\
\hline Good & 53 & $107 \pm 10$ & 52 & $111 \pm 10$ \\
\hline \multicolumn{5}{|l|}{$\mathrm{Ca}$ intake(mg/day) } \\
\hline$<900$ & 78 & $106 \pm 9$ & 80 & $110 \pm 10$ \\
\hline$\geq 900$ & 8 & $100 \pm 8$ & 5 & $105 \pm 5$ \\
\hline \multicolumn{5}{|c|}{ Ionized $\mathrm{Ca}(\mathrm{mmol} / \mathrm{L})$} \\
\hline$<1.03$ & 21 & $105 \pm 8$ & 26 & $110 \pm 10$ \\
\hline $1,03-1,23$ & 65 & $105 \pm 10$ & 59 & $109 \pm 10$ \\
\hline
\end{tabular}

${ }^{*} \mathrm{p} 0.05$

There was no significant difference between systolic blood pressure and variables, except nutritional status (Table 5).
Table 6. Association between diastolic blood pressure and variable factors on 24 th, 36 th weeks of gestation.

\begin{tabular}{|c|c|c|c|c|}
\hline \multirow{2}{*}{ Variable } & \multicolumn{4}{|c|}{$\begin{array}{l}\text { Diastolic Blood Pressure } \\
\text { ( } \mathrm{mmHg} \text { ) }\end{array}$} \\
\hline & n & 24 weeks & $\mathrm{n}$ & 36 weeks \\
\hline \multicolumn{5}{|l|}{ Age } \\
\hline$<-24$ & 39 & $70 \pm 6$ & 39 & $70 \pm 7$ \\
\hline $25-29$ & 38 & $70 \pm 7$ & 37 & $71 \pm 8$ \\
\hline $30->$ & 9 & $71 \pm 6$ & 9 & $72 \pm 5$ \\
\hline \multicolumn{5}{|l|}{ Education } \\
\hline Low & 5 & $73 \pm 5$ & 5 & $72 \pm 5$ \\
\hline Middle & 66 & $70 \pm 6$ & 66 & $73 \pm 8$ \\
\hline High & 15 & $71 \pm 8$ & 14 & $72 \pm 7$ \\
\hline \multicolumn{5}{|l|}{ Income } \\
\hline Low & 20 & $71 \pm 7$ & 19 & $74 \pm 9$ \\
\hline Middle & 66 & $70 \pm 6$ & 66 & $72 \pm 8$ \\
\hline \multicolumn{5}{|l|}{ Nutritional status } \\
\hline Under & 33 & $67 \pm 6 *$ & 33 & $71 \pm 8$ \\
\hline Good & 53 & $72 \pm 7$ & 52 & $74 \pm 8$ \\
\hline \multicolumn{5}{|l|}{$\mathrm{Ca}$ intake(mg/day) } \\
\hline$<900$ & 78 & $71 \pm 7$ & 80 & $73 \pm 8$ \\
\hline$\geq 900$ & 8 & $67 \pm 5$ & 5 & $68 \pm 6$ \\
\hline \multicolumn{5}{|c|}{ Ionized $\mathrm{Ca}(\mathrm{mmol} / \mathrm{L})$} \\
\hline$<1.03$ & 21 & $70 \pm 5$ & 26 & $73 \pm 8$ \\
\hline $1,03-1,23$ & 65 & $70 \pm 7$ & 59 & $71 \pm 8$ \\
\hline
\end{tabular}

* p 0.05

There was no significant difference between diastolic blood pressure and variables, except nutritional status (Table 6).

Table 7. Mean value and standard deviation of calorie intake, protein intake, $\mathrm{Ca}$ intake and serum ionized $\mathrm{Ca}$ concentration in normal and preeclamptic group.

\begin{tabular}{|c|c|c|c|}
\hline & Preeclampsia & Normal & $\mathrm{p}$ \\
\hline \multicolumn{4}{|c|}{ Calory intake (Kcal/day) } \\
\hline \multicolumn{4}{|c|}{ Week of gestation } \\
\hline 32 weeks & $1482 \pm 184$ & $1643 \pm 362$ & $>0.05$ \\
\hline 36 weeks & $1753 \pm 119$ & $1618 \pm 306$ & $>0.05$ \\
\hline \multicolumn{4}{|l|}{ Protein intake (g/day) } \\
\hline \multicolumn{4}{|c|}{ Week of gestation } \\
\hline 32 weeks & $54 \pm 7$ & $64 \pm 16$ & $>0.05$ \\
\hline 36 weeks & $62 \pm 16$ & $73 \pm 14$ & $>0.05$ \\
\hline \multicolumn{4}{|c|}{ Calcium intake (mg/day) } \\
\hline \multicolumn{4}{|c|}{ Week of gestation } \\
\hline 32 weeks & $455 \pm 101$ & $617 \pm 206$ & $>0.05$ \\
\hline 36 weeks & $508 \pm 123$ & $567 \pm 208$ & $>0.05$ \\
\hline \multicolumn{4}{|c|}{ Ionized Ca con. $(\mathrm{mmol} / \mathrm{L})$} \\
\hline \multicolumn{4}{|c|}{ Week of gestation } \\
\hline 24 weeks & $1,07 \pm 0,05$ & $1,06 \pm 0,06$ & $>0.05$ \\
\hline 36 week & $1,03 \pm 0,03$ & $1,06 \pm 0,05$ & $>0.05$ \\
\hline
\end{tabular}


There was no significant difference between calorie intake, protein intake, $\mathrm{Ca}$ intake and serum ionized $\mathrm{Ca}$ among Preeclamptic and Normal subjects.

Table 8. Association between Preeclampsia and Selected variables.

\begin{tabular}{|c|c|c|c|c|}
\hline & \multicolumn{2}{|c|}{ Preeclampsia } & \multirow[b]{2}{*}{ Odds ratio } & \multirow[b]{2}{*}{$(95 \% \mathrm{CI})$} \\
\hline & $+(\%)$ & $-(\%)$ & & \\
\hline \multicolumn{5}{|l|}{ Age } \\
\hline$<-24$ & $4(10.3)$ & $35(89.7)$ & 1.68 & $(0.29-10.25)$ \\
\hline $25-29 *$ & $3(7.9)$ & $35(82.1)$ & & \\
\hline $30->*$ & 0 & $9(100)$ & & \\
\hline \multicolumn{5}{|l|}{ Education } \\
\hline Low* & 0 & $5(100)$ & 0.49 & $(0.07-4.14)$ \\
\hline Middle * & $5(7.6)$ & $61(92.4)$ & & \\
\hline High & $2(13.3)$ & $13(86.7)$ & & \\
\hline \multicolumn{5}{|l|}{ Income } \\
\hline Low & $3(15.0)$ & $17(85.0)$ & 2.74 & $(0.43-16.62)$ \\
\hline Middle & $6(6.1)$ & $62(93.9)$ & & \\
\hline \multicolumn{5}{|l|}{ Nutritional status } \\
\hline Under & $4(12.1)$ & $29(87,9)$ & 2.30 & $(0.40-14.15)$ \\
\hline Good & $3(5.7)$ & $50(94.3)$ & & \\
\hline \multicolumn{5}{|c|}{$\mathrm{Ca}$ intake(mg/day) } \\
\hline$<900$ & $7(8.6)$ & $74(91.4) * *$ & - & - \\
\hline$\geq 900$ & 0 & $5(100)$ & & \\
\hline \multicolumn{5}{|c|}{ IonizedCa $\operatorname{con}(\mathrm{mmol} / \mathrm{L})$} \\
\hline$<1.03$ & $2(7.4)$ & $25(92.6)$ & 0.86 & $(0.11-5.58)$ \\
\hline $1,03-1,23$ & $5(8.5)$ & 54 (91.5) & & \\
\hline
\end{tabular}

* Grouped for statistical analysis.

$* * \mathrm{p}>0.05$

There was no significant difference between Preeclampsia and Selected variables (Table 8).

\section{DISCUSSION}

Within the study period, serum ionized $\mathrm{Ca}$ declined from $1.06 \mathrm{mmol} / \mathrm{l}$ in 24 weeks of gestation to 1.05 $\mathrm{mmol} / \mathrm{l}$ in 36 weeks of gestation. Dependent $t$ test statistical analysis showed that the decreased was not significant $(\mathrm{p}>0.05)$. In the same period, $\mathrm{Ca}$ intake slightly decreased from $568 \mathrm{mg} /$ day at 24 weeks of gestation to $563 \mathrm{mg} /$ day at 36 weeks of gestation. Ca intake at 24,32 and 36 weeks of gestation were $63.1 \%$, $67.1 \%$ and $62.6 \%$ of Recommended Dietary Allowances (RDA) for pregnant women $(900 \mathrm{mg} /$ day) respectively (Table 2). Data of Ca intake were collected by recall $2 \times 24$ hours recall method. It is a very weak assessment because of its dependance on the of subjects to recall food intake. The value of $2 \times 24$ hours recall in assesing the average intake of groups is well established. In this study, multiple $2 \times 24$ hours recall at 24,32 and 36 weeks of gestation improve the accuracy of individual intake estimates. ${ }^{9}$ It was mentioned before, that during pregnancy the demand for $\mathrm{Ca}$ is high due to increase of its requirement. On the other hand, the maternal adjustment mechanism that accomodates this high $\mathrm{Ca}$ requirement is partially inhibited during this period. Increased renal $\mathrm{Ca}$ excretion and maternal bone $\mathrm{Ca}$ occurs during pregnancy. However, intestinal absorption can increase from $27 \%$ before pregnancy to as high as $50 \%$ during gestation to maintain serum ionized $\mathrm{Ca}$ concentration within normal limit. In this case a compensatory increase in parathyroid hormone levels has been observed. ${ }^{10}$ This mechanism will maintain ionized $\mathrm{Ca}$ concentration within normal limit ( $1.03-1.23 \mathrm{mmol} / \mathrm{L}$ ).

Parathyroid hormone serum level would involve an increase in the intracellular cytosol concentration of $\mathrm{Ca}$ in several types of cells, such as kidney, liver and HeLa cells. Two mechanisms can mediate this action: an increase in $\mathrm{Ca}$ cellular membrane permeability and activation of adenyl cyclase with an increase of cyclic adenosine monophosphate. Consequently $\mathrm{Ca}$ is liberated from the mitochondria to the cytosol. The concentration of intracellular (cytosolic) free $\mathrm{Ca}$ in vascular smooth muscle cells determines the degree of tension in the muscle and is a trigger for musclular contraction. This hypothesis suggest that a vasoconstrictive effect, with a rise in blood pressure, result from an increase in vascular smooth muscle tension. ${ }^{11}$

Hypertension with edema and or proteinuria called Preeclampsia. The uteroplacental bed holds the key to the understanding of the cause and pathogenesis of Preeclampsia. The defect seen in Preeclampsia is a lack of or an incomplete invasion of trophoblast into the maternal spiral arteries. This change in development within the spiral arteries establishes a mechanism whereby endothelial cell injury begins with the production of mitogens, a decrease of prostacyclines and an increase of thromboxan A-II, a vasoconstrictor and platelet proaggregator. The placental production of prostacycline is decreased significantly. This result in less dilatation in the cardiovascular system with a relative greater balance of the vasoconstrictor, thromboxan, which probably contributes to the vasoconstriction. These gradual and subtle changes ultimately lead to an alteration in cardiovascular reactivity and the eventual development of hypertension. ${ }^{12}$ This condition with increased vascular smooth muscle tension caused increased sensitivity to circulating pressors.

In this study there were 7 preeclamptic subjects, 1 was diagnosed at 32 weeks of gestation and the other at 36 weeks of gestation $(8.1 \%)$. When compared with Irawati, ${ }^{2}$ incidence of Preeclampsia in this study was lower. This was due to subjects having normal blood 
pressure at enrollment, normal blood urea and creatinine and follow up done until 36 weeks of gestation.

Statistical analysis between Preeclampsia and some variables such as age, education, income, nutritional status, $\mathrm{Ca}$ intake dan serum ionized $\mathrm{Ca}$ were not significant. Neverless $\mathrm{Ca}$ intake in the Preeclamptic group was lower than the Normal group at 32 and 36 weeks of gestation (Table 9).

We have observed in this study:

1. The incidence of Preeclampsia in this study was $8.1 \%$.

2. There were no relationship between $\mathrm{Ca}$ intake, serum ionized $\mathrm{Ca}$ and elevated blood pressure after 24 weeks of gestation.

\section{Acknowledgment}

The authors wish to express our thanks to Dr. Sunarto Wironagoro, DSOG Head of "Rumah Sakit Bersalin Budi Kemuliaan" for his valuables help in preparation of this study.

\section{REFERENCES}

1. Departemen Kesehatan RI, Pola dan Faktor-faktor yang Berhubungan Dengan Kematian Ibu Melahirkan di Rumah Sakit Kelas C dan D di Indonesia. Jakarta,1995.
2. Irawati D. Pola Tekanan Darah pada Kehamilan "normotensif" dan preeklampsia serta pengaruh paritas. Thesis. Jakarta: Universitas Indonesia, 1985

3. Zuspan FP. New Concepts in the Understanding of Hypertensive Diseases During Pregnancy. In : Sibai BM, editor. Clinics in Perinatology. Philadelphia: Saunders WB, 1991;18:653-9.

4. Bardosono S. Magnesium and Blood Pressure Changes in Pregnancy. Thesis. Jakarta: Universitas Indonesia ,1992.

5. Catatan Medik Instalasi Gawat Darurat. Rumah Sakit Umum Pusat Nasional Cipto Mangunkusumo. Jakarta, 1994

6. Forbes GB. Calcium Accumulation by the Human Fetus. Pediatrics, $1976 ; 57: 976$.

7. Belizan JM, Pineda O, Sainz E, Menendez LA, Villar J. Rise of blood pressure in calcium-deprived pregnant rats. Am J Obstet Gynecol.1981; 141:163-9.

8. Repke JT, Villar J. Pregnancy-induced hypertension and low birth weight: the role of calcium. Am J Clin Nutr 1991; 54: $237 \mathrm{~S}-41 \mathrm{~S}$.

9. Witschi JC. Short-Term Dietary Recall and Recording Methods. In: Willett W, editor. Nutritional Epidemiology. New York: Oxford University Press, 1990:52-68.

10. Heaney RP, Skillman TG. Calcium metabolism in normal human pregnancy. J Clin Endocrinol Metab, 1971; 36: 66170.

11. Belizan JM, Villar J, Repke J. The relationship between calcium intake and pregnancy-induced hypertension: Up-todate evidence. Am J Obstet Gynecol 1988; 158: 898-902.

12. Zuspan FP. New Concepts in the Understanding of Hypertensive Diseases During Pregnancy. In: Sibai BM, editor. Clinics in Perinatology. Philadelphia: Saunders WB,1991; $18: 4: 653-9$. 